\title{
6 种温带森林碳密度与碳分配
}

\author{
张全智，王传宽*
}

东北林业大学林学院, 哈尔滨 150040

* 联系人, E-mail: wangck-cf@nefu.edu.cn

收稿日期: 2010-02-02; 接受日期: 2010-03-10

国家自然科学基金(批准号: 30625010)、国家林业局林业公益性行业科研专项(批准号: 200804001)和“十一五”国家林业科技支撑计划(批准 号: 2006BAD03A0703)资助项目

摘要量化森林碳储量及其分配格局是森林碳循环和陆地生态系统模型的重要研究内容. 采用 样地清查和异速生长方程法测定了相同气候条件下林龄相近(42 59 年生)的 6 种典型温带森林类型 (杨桦林、硬阔叶林、红松林、兴安落叶松林、杂木林和蒙古柇林) 的碳密度和碳分配格局。结果表 明，所处的立地条件和植被组成不同的 6 种温带森林，其生态系统组分碳密度 (除碎屑碳库外) 差 异不显著, 但用林分胸高断面积标准化之后则存在显著差异. 6 种温带森林的总碳密度在 186.9 349.2 $\mathrm{tC} / \mathrm{hm}^{2}$ 之间波动; 其中, 植被碳密度、碎屑碳密度和土壤碳密度分别在 86.3 122.7,

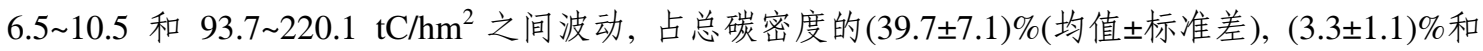
$(57.0 \pm 7.9) \%$. 在植被碳库中, 乔木层占 $99 \%$ 以上. 叶生物量、中细根(直径 $<5 \mathrm{~mm}$ )生物量、根冠比、 中细根生物量与叶生物量之比分别在 $2.08 \sim 4.72 \mathrm{tC} / \mathrm{hm}^{2}, 0.95 \sim 3.24 \mathrm{tC} / \mathrm{hm}^{2}, 22.0 \%$ 28.3\%, $34.5 \%$ 122.2\% 之间波动. 6 种森林中, 红松林的叶生产效率(总生物量与叶生物量之比)最低(22.6 $\mathrm{g} / \mathrm{g}$ ), 兴安落叶松林的中细根生产效率(总生物量与中细根生物量之比)最高 $(124.7 \mathrm{~g} / \mathrm{g}$ ). 除蒙古柇林 外, 其他 5 种森林的中细根碳密度(包括死活中细根量)均随土壤层次加深而下降; 而蒙古柇林的中 细根碳密度的垂直分布却有下移趋势. 两种人工林(红松林和兴安落叶松林)的粗木质残体碳密度显 著低于 4 种天然林. 本研究指出, 特定森林碳分配格局的分异主要受植被类型、经营历史、局域土 壤的水分和养分有效性等因素的共同作用，同时也为温带森林碳循环模型提供了重要的构建和校 验参数.

关键词

生物量

碳储量

碳库

碳分配

根冠比
森林面积约占陆地面积的 $1 / 3$, 却包含了陆地生 态系统地上碳库的 $80 \%$ 和地下碳库的 $40 \%$, 含碳量高 达 $638 \mathrm{Gt}\left(1 \mathrm{Gt}=1 \times 10^{9} \mathrm{t}\right)$, 其中生物量碳约为 $283 \mathrm{Gt}^{[1]}$. 尤其是北半球中高纬度的森林, 具有很高的碳吸收 潜力 ${ }^{[2 \sim 5]}$, 其净初级生产力占陆地生态系统的 $60 \%$ 以 上 $^{[6]}$, 因而在固碳释氧、减缓气候变暖 $\left.{ }^{[7} 10\right]$ 、维护全 球碳平衡 ${ }^{[11,12]}$ 等方面起重要作用. 因此, 探索森林碳
分配格局及其影响因子对于构建陆地生态系统模型 和评价预测森林在全球碳循环中的作用非常重要 ${ }^{[13]}$.

森林碳分配格局受植被组成、林龄、立地条件、 林分特征等因素的影响. Wang 等人 ${ }^{[14]}$ 在比较林龄相 近的 3 种兴安落叶松原始林碳分配时发现, 杜香-兴 安落叶松林的植被碳库占生态系统总碳库的 $13.5 \%$, 而杜鹃-兴安落叶松林的植被碳库却占 $63.1 \%$. 即使

英文版见: Zhang Q Z, Wang C K. Carbon density and distribution of six Chinese temperate forests. Sci China Life Sci, 2010, 53: 831-840, doi: $10.1007 / \mathrm{s} 11427-010-4026-0$ 
相似的森林类型, 其总碳密度随林龄增大而增大, 且 幼龄林常以土壤和碎屑碳库为主(占 $85 \%$ 99\%), 而 老龄林则以植被碳库为主(占 $54 \%$ 64\% $)^{[15 \sim 18]}$. 另外, 林龄相同的北方黑云杉林, 处于排水良好立地条件的 植被碳库所占比例显著高于处于排水不良的，而前者 的土壤碳库所占比例则显著低于后者 ${ }^{[19]}$. 最近, Zhu 等人 ${ }^{[20]}$ 报道, 长白山温带原始林的总碳密度、植被碳 密度及其分配系数均随海拔(700 2000 m) 的升高而降 低. 此外, 也有研究指出, 扭叶松幼龄林碳密度随林 分密度增大而增加 ${ }^{[16,21]}$. 由此可见, 地域、森林类型及 其特征的差异使森林碳密度和碳分配格局分异显著, 从而使森林碳循环及其时空变化规律复杂化 ${ }^{[2,22,23]}$. 另外, 林分结构和干扰历史等相关研究的贵乏进一步 加大了对区域碳源汇格局模型预测及其驱动机制的 认识的不确定性 ${ }^{[24,25]}$.

东北地区森林面积和蓄积量均占全国总量的 $1 / 3$ 以上, 在全国和区域碳平衡中起至关重要的作用 ${ }^{[26]}$. 同时, 该地区也是中国气候变化最显著、植被对气候 变化响应的敏感地带 ${ }^{[24]}$. 过去 10 年中, 该地区作为 中国天然林保护工程实施的重点地区之一, 其森林 碳源汇功能及其时空格局可能因经营活动和气候变 化而发生变化. Piao 等人 ${ }^{[27]}$ 采用地面实测尺度转换、 大气反演和生态系统模型相结合的方法分析了 20 世 纪 80 90 年代中国陆地生态系统碳收支变化, 指出由 于森林的过度采伐和退化, 东北森林呈现出由碳汇 转变为碳源的趋势. 目前, 对东北温带森林碳密度和 碳分配格局的系统量化研究尚少 ${ }^{[24,25]}$.

本研究作为东北东部温带森林碳循环综合研究 的一部分 ${ }^{[26,28,29]}$, 旨在量化 6 种典型温带森林(杨桦 林、硬阔叶林、红松林、兴安落叶松林、杂木林和蒙
古栎林)的碳分配格局，探索其控制因子，为温带森 林碳循环模型提供可靠的构建和校验参数, 以减少 森林碳收支估测和预测的不确定性.

\section{1 材料与方法}

\section{1 研究地概况}

研究地设在黑龙江帽儿山森林生态站 $\left(45^{\circ} 20^{\prime} \mathrm{N}\right.$, $127^{\circ} 30^{\prime} \mathrm{E}$ ). 平均海拔 $400 \mathrm{~m}$, 平均坡度 $10^{\circ} \sim 15^{\circ}$, 地带 性土壤为暗棕色森林土. 该地区气候属大陆性季风 气候, 平均年降水量约 $700 \mathrm{~mm}$, 平均年蒸发量约 880 $\mathrm{mm}$, 年均气温 $2.8^{\circ} \mathrm{C}^{[26]}$. 现有植被是原地带性植被阔 叶红松林经干扰后形成的天然次生林和人工林, 主 要组成树种包括蒙古栋(Quercus mongolica Fisch.)、白 桦(Betula platyphylla Suk.)、黄菠萝(Phellodendron amurense Rupr.)、胡桃梑(Juglans mandshurica Maxim.)、 水曲柳(Fraxinus mandshurica Rupr.)、山杨(Populous davidiana Dode)、五角槭(Acer mono Maxim.)、紫椴 (Tilia amurensis Rupr.)、春榆(Ulmus japonica (Rehc.) Sarg.)、红松(Pinus koraiensis Sieb. et Zucc.)、兴安落叶 松(Larix gmelinii Rupr.)等, 代表了东北东部山区典型 的森林类型. 选取处于相同气候条件下林龄 (皆伐后 的年数)相近的 6 种典型森林类型, 即杨桦林、硬阔叶 林、红松人工林、兴安落叶松人工林、杂木林和蒙古栎 林, 其林分特征和立地状况见表 1. 主要灌木包括: 丁 香(Syringa spp.)、卫矛(Euonymus spp.)、绣线菊(Spiraea spp.)、溲疏(Deutzia spp.)、刺五加(Acanthopanax spp.)、 五味子(Schizandra chinensis) 等; 主要草本植物: 苔 草(Carex spp.)、山茄子(Brachybotrys paridiformis)、 白花碎米荠(Cardamine leucantha)、木贼(Equisetum

\section{表 16 种森林类型的立地状况和乔木层特性 ${ }^{a)}$}

\begin{tabular}{|c|c|c|c|c|c|c|c|c|c|}
\hline $\begin{array}{l}\text { 森林 } \\
\text { 类型 }\end{array}$ & 坡位 & $\begin{array}{c}\text { 坡度 } \\
1^{\circ}\end{array}$ & $\begin{array}{c}\text { 林龄 } \\
\text { /年 }\end{array}$ & $\begin{array}{c}\text { 密度 } \\
/ \text { 株· } \mathrm{hm}^{-2} \\
\end{array}$ & $\begin{array}{c}\text { 胸高断面积 } \\
/ \mathrm{m}^{2} \cdot \mathrm{hm}^{-2}\end{array}$ & $\begin{array}{c}\text { 平均胸径 } \\
/ \mathrm{cm}\end{array}$ & $\begin{array}{c}\text { 平均树高 } \\
\text { /m }\end{array}$ & 起源 & $\begin{array}{c}\text { 树种组成 } \\
(1 / 10)\end{array}$ \\
\hline 杨桦林 & 中坡 & 16 & 58 & $2050(44)$ & $29.8(6.3)$ & $11.17(0.91)$ & $10.42(0.56)$ & 天然更新 & 5PD1FM1TA1AM1QM1BP+JM+PA+UJ \\
\hline 硬阔叶林 & 沟谷 & 7 & 53 & $1889(910)$ & $31.1(6.2)$ & $14.40(4.53)$ & $11.27(2.43)$ & 天然更新 & 6FM2JM1QM1UJ+AM-PA \\
\hline 红松林 & 中坡 & 12 & 42 & $2528(215)$ & $38.3(0.8)$ & $12.91(0.51)$ & $12.05(0.35)$ & 人工更新 & 7PK2BP1FM-QM \\
\hline $\begin{array}{c}\text { 兴安落叶 } \\
\text { 松林 }\end{array}$ & 沟谷 & 3 & 50 & $1417(741)$ & $32.8(2.0)$ & $14.25(1.9)$ & $12.27(0.36)$ & 人工更新 & 9LG1UJ \\
\hline 杂木林 & 中坡 & 14 & 58 & $2289(435)$ & $33.7(2.6)$ & $10.94(1.44)$ & $9.99(0.96)$ & 天然更新 & 2JM2PD1PA1TA1AM1QM1UJ1BP \\
\hline 蒙古栎林 & 上坡 & 23 & 59 & $2111(48)$ & $37.8(1.1)$ & $12.17(0.07)$ & $11.00(0.26)$ & 天然更新 & 10QM+TA+BP \\
\hline
\end{tabular}

a) 括号内数值为标准差 $(n=3)$. PD, AM, BP, LG, QM, JM, FM, TA, PK, PA 和 UJ 分别示山杨、五角槭、白桦、兴安落叶松、蒙古栋、胡 桃楸、水曲柳、紫椴、红松、黄菠萝和春榆. 树种组成中的数字示该树种胸高断面积所占的成数.,+- 分别示组成比例 $<5 \%$ 和 $<2 \%$ 
spp.)、野山芹(Ostericum spp.)、荨麻(Urtica spp.) 等.

\section{2 森林碳密度测定}

(1) 乔木层碳密度. 乔木层包括树高 $>1.37 \mathrm{~m}$ 的 所有树木. 在选定的 6 种森林类型中各随机设立 3 块 $20 \mathrm{~m} \times 30 \mathrm{~m}$ 的固定样地, 于 2007 年秋季每木检尺乔 木层所有树木的胸径 $(\mathrm{DBH}, 1.37 \mathrm{~m})$. 利用该样地建 立的各个树种的异速生长方程 ${ }^{[26]}$ 及相应的生物量组 分(树干、树枝、叶和粗根)碳浓度 ${ }^{[30]}$, 测算乔木层各 组分的碳密度, 累加得到乔木层碳密度.

（2）林下植被层碳密度. 林下植被包括草本、灌 木和树高 $<1.37 \mathrm{~m}$ 的乔木幼树. 在上述每块固定样地 周围，随机设立植被条件一致的 3 块 $3 \mathrm{~m} \times 3 \mathrm{~m}$ 的临时 样方, 于 2007 年 8 月(植被生物量达到最大时)采用 收获法测定所有林下植被的鲜重; 取样后采用烘干 法 $\left(65^{\circ} \mathrm{C}\right)$ 测定其含水率, 并用 Multi N/C 3000 分析仪 (Analytik Jena AG, Germany)测定其碳浓度; 最后, 利用所测得的生物量干重和碳浓度换算成林下植被 层碳密度.

(3) 根系碳密度. 根系包括粗根 (直径>5 mm)、 中根 (直径 2 5 mm) 和细根 (直径 $<2 \mathrm{~mm}$ ). 粗根碳密度 采用异速生长方程法 ${ }^{[26]}$ 获得(详见乔木层碳密度)。中 细根碳密度采用连续根钻法测定. 在每块固定样地 周围缓冲区 $(2 \sim 3 \mathrm{~m})$ 内随机选取 8 个样点, 于 2008 年 5 10 月期间, 每月一次用内径为 $10 \mathrm{~cm}$ 的根钻取土 柱, 深至 $50 \mathrm{~cm}$ (此深度已基本没有中细根分布) ${ }^{[29]}$, 每 $10 \mathrm{~cm}$ 一层, 共分 5 层. 将取回的土柱样品在网笛 上洗净后，按直径将根分级，剔除粗根；同时根据根 的外形、颜色、弹性等将中细根分成死根和活根 ${ }^{[31]}$; 将分级后样品在 $65^{\circ} \mathrm{C}$ 下烘干, 测其干重(精确至 0.001 $\mathrm{g})$, 并用上述方法测其碳浓度; 最后根据根钻面积、 6 个月中细根生物量平均值和碳浓度, 求得中细根碳 密度.

(4) 碎屑碳密度. 碎屑包括枯立木、粗木质残体 (CWD)和林地枯落物层. 枯立木碳密度: 利用样地清 查数据和相应的异速生长方程 ${ }^{[26]}$ 估算枯立木的树干、 枝和粗根量, 再乘以相应组分的碳浓度 ${ }^{[30]}$ 获得. CWD 碳密度: 采用样地清查法测定每个样地中所有 的 CWD 质量, 再乘以其碳浓度获得. 长度 $<2 \mathrm{~m}$ 的 CWD 采取直接称重法测定其质量; 而长度 $>2 \mathrm{~m}$ 的 CWD 则测定其长度和两端的直径, 然后将 CWD 看
作圆台体, 采用公式(1)求得每根 CWD 的质量. 同时, 取样测定 CWD 的含水量、木材密度和碳浓度.

$$
M_{i}=\frac{1}{12} \times \pi \times L_{i} \times\left(D_{a i}^{2}+D_{a i} \times D_{b i}+D_{b i}^{2}\right) \times \rho_{i} \times C_{i},
$$

$M_{i}$ 为第 $i$ 根 CWD 的碳密度; $L_{i}$ 为第 $i$ 根 CWD 的长度; $D_{a i}$ 和 $D_{b i}$ 分别为第 $i$ 根 CWD 的两端直径; $\rho_{i}$ 为第 $i$ 根 $\mathrm{CWD}$ 的木材密度; $C_{i}$ 为 CWD 的碳浓度. 林地枯落物 层碳密度: 在每块样地内随机设置 6 个 $1 \mathrm{~m} \times 1 \mathrm{~m}$ 的样 方, 收取所有的枯落物, 测定其重量、含水率和碳浓 度, 最后获得林地枯落物层碳密度.

(5) 土壤碳密度. 2004 年 8 月, 在每块固定样地 边界周围的缓冲区 $(2 \sim 3 \mathrm{~m})$ 内, 随机挖取 3 个土壤剖 面，按照土壤剖面发生层(即 $\mathrm{O}, \mathrm{A}, \mathrm{AB}, \mathrm{B}$ 层)，测定土 壤层次的厚度和容重; 同时每层取约 $500 \mathrm{~g}$ 土样，用 multi C/N 3000 分析仪(Analytik Jena AG, Germany)测 定土壤有机碳浓度; 最后根据土层厚度、容重和相应 的碳浓度求得土壤碳密度. 详见参考文献[24].

\section{3 数据分析}

分别基于单位林地面积和单位胸高断面积(BA) 两种方式比较 6 种森林类型的碳密度和碳分配格局. 应用 SPSS15.0(SPSS Inc.2006)统计软件的方差分析 (ANOVA)和 LSD 检验比较森林类型之间碳密度和碳 组分的差异. 所有数据分析均以样地为实验单位.

\section{2 结果}

\section{1 森林碳密度}

方差分析显示, 6 种森林类型之间总碳密度 $\left(F_{5,12}=\right.$ $2.4, P=0.102)$ 、植被碳密度 $\left(F_{5,12}=2.3, P=0.106\right)$ 和土壤 碳密度 $\left(F_{5,12}=2.0, P=0.147\right)$ 均无显著差异, 分别在 186.9 349.2, 86.3 122.7 和 93.7 220.1 tC/ $/ \mathrm{hm}^{2}$ 间波动 (表 2). 然而, 森林类型之间碎屑碳密度差异显著 $\left(F_{5,12}=4.7, P=0.014\right)$, 其中以硬阔叶林最低 $(6.5$ $\left.\mathrm{tC} / \mathrm{hm}^{2}\right)$, 蒙古楿林最高 $\left(10.5 \mathrm{tC} / \mathrm{hm}^{2}\right)$. 两种人工林(红 松林和落叶松林)的 CWD 碳密度显著低于 4 种天然 林. 乔木层碳密度占植被碳库的 $99 \%$ 以上(表 2), 在 85.4 121.4 tC/ $\mathrm{hm}^{2}$ 之间波动.

用胸高断面积(BA)标准化(即生态系统组分碳密 度/乔木层胸高断面积之比)后, 6 种森林类型之间的 总碳密度 $\left(F_{5,12}=5.0, P=0.01\right)$ 、植被碳密度 $\left(F_{5,12}=18.0\right.$, $P<0.001)$ 和土壤碳密度 $\left(F_{5,12}=3.2, P=0.046\right)$ 均存在显 
表 26 种森林类型碳密度和碳分配(单位: $\left.\mathbf{t C} / \mathbf{h m}^{2}\right)^{\mathbf{a})}$

\begin{tabular}{|c|c|c|c|c|c|c|c|}
\hline \multirow{2}{*}{ 生态系统组分 } & \multicolumn{7}{|c|}{ 森林类型 } \\
\hline & 杨桦林 & 硬阔叶林 & 红松林 & 兴安落叶松林 & 杂木林 & 蒙古栎林 & 平均 \\
\hline \multicolumn{8}{|l|}{ 植被碳库 } \\
\hline 乔木 & $85.4(18.5)$ & $121.4(28.3)$ & $99.3(3.8)$ & $106.4(3.2)$ & $101.3(6.7)$ & $115.1(3.8)$ & $104.9(17.0)$ \\
\hline 灌木和草本 & $0.86(0.57)$ & $1.23(1.57)$ & $0.04(0.04)$ & $0.17(0.05)$ & $0.41(0.23)$ & $0.36(0.10)$ & $0.51(0.72)$ \\
\hline 总植被碳库 & $86.3(18.8)$ & $122.7(28.6)$ & $99.4(3.8)$ & $106.6(3.2)$ & $101.7(6.5)$ & $115.5(3.9)$ & $105.4(17.1)$ \\
\hline \multicolumn{8}{|l|}{ 碎屑碳库 } \\
\hline 林地枯落物 & $2.6(1.1)$ & $2.6(0.3)$ & $4.1(0.3)$ & $9.6(1.4)$ & $4.6(2.4)$ & $4.5(1.5)$ & $4.7(2.7)$ \\
\hline 粗木质残体 & $1.8(0.9)$ & $2.1(1.2)$ & $0.3(0.1)$ & $0.1(0.1)$ & $2.6(0.7)$ & $3.5(2.3)$ & $1.7(1.6)$ \\
\hline 枯立木 & $2.5(2.0)$ & $1.7(1.4)$ & $3.2(0.5)$ & $0.2(0.2)$ & $2.2(1.4)$ & $2.6(1.0)$ & 2.1(1.4) \\
\hline 总碎屑碳库 & $6.9(0.7)^{\mathrm{cd}}$ & $6.5(2.1)^{\mathrm{d}}$ & $7.6(0.3)^{\mathrm{bcd}}$ & $10.0(1.5)^{\mathrm{ab}}$ & $9.3(1.9)^{\mathrm{abc}}$ & $10.5(0.8)^{\mathrm{a}}$ & $8.5(2.0)$ \\
\hline 土壤碳库 & $93.7(11.0)$ & $220.1(62.7)$ & $162.1(31.6)$ & 181.1(41.1) & 184.2(99.4) & $125.0(40.7)$ & $161.0(62.9)$ \\
\hline 总碳库 & $186.9(27.8)$ & $349.2(82.1)$ & 269.1(33.0) & $297.7(40.2)$ & 295.2(101.2) & $251.0(44.3)$ & $274.8(72.5)$ \\
\hline
\end{tabular}

a) $\bar{x} \pm \mathrm{SD} . \mathrm{a} \sim \mathrm{d}$ : 同一生态系统组分在不同森林类型之间 $\mathrm{LSD}$ 检验显著性差异分组 $(\alpha=0.05)$

著差异, 分别在 $6.35 \sim 11.3,2.80 \sim 4.14$ 和 3.21 7.16 $\mathrm{tC} / \mathrm{m}^{2}$ 之间波动; 而碎屑碳密度差异却不显著 $\left(F_{5,12}=\right.$ $2.5, P=0.09)$. 单位 $\mathrm{BA}$ 的总碳密度、植被碳密度、土 壤碳密度均以硬阔叶林最高(图 1).

\section{2 森林碳分配}

碳分配格局随森林类型和生态系统组分而变(图 2). 方差分析显示, 生态系统组分间差异显著 $\left(F_{2,51}=358\right.$, $P<0.01)$. 碎屑碳库、植被碳库和土壤碳库的平均分配 比例分别为 $(3.3 \pm 1.1) \%(\bar{x} \pm \mathrm{SD}),(39.7 \pm 7.1) \%$ 和

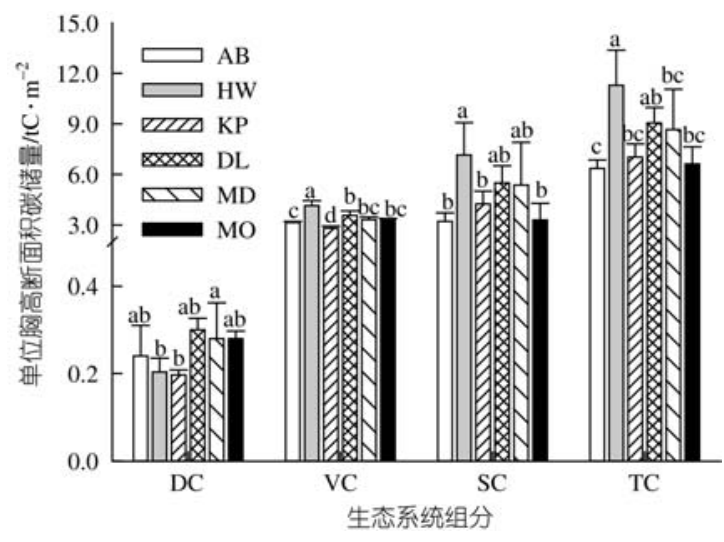

图 16 种森林类型单位胸高断面积生态系统组分的 碳储量

$\mathrm{DC}, \mathrm{VC}, \mathrm{SC}$ 和 $\mathrm{TC}$ 分别示碎屑碳库、植被碳库、土壤碳库和总碳 库. AB, HW, KP, DL, MD 和 MO 分别示杨桦林、硬阔叶林、红松林、 兴安落叶松林、杂木林和蒙古栎林. 误差线是标准差 $(n=3)$. a c 示 同一生态系统组分在不同森林类型之间 LSD 检验显著性差异分组 $(\alpha=0.05)$

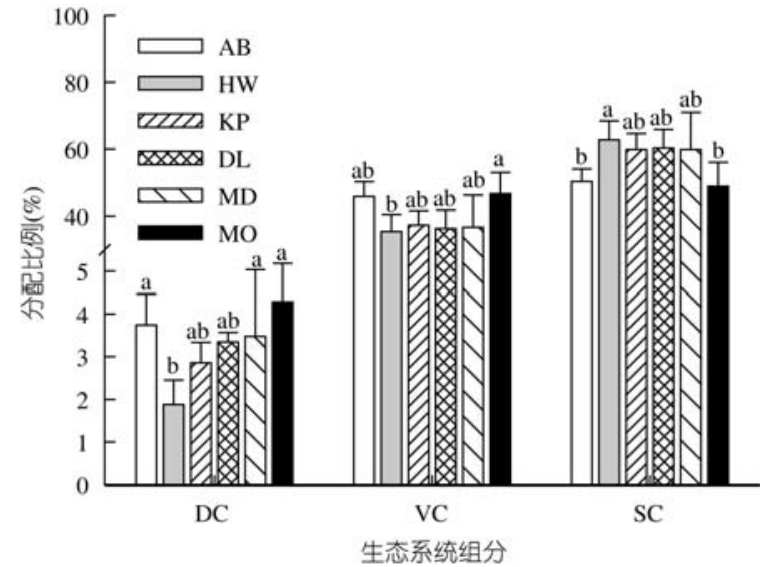

图 26 种森林类型总碳库的分配比例

$\mathrm{DC}, \mathrm{VC}$ 和 SC 分别示碎屑碳库、植被碳库和土壤碳库; $\mathrm{AB}, \mathrm{HW}$, $\mathrm{KP}, \mathrm{DL}, \mathrm{MD}$ 和 MO 分别示杨桦林、硬阔叶林、红松林、兴安落叶 松林、杂木林和蒙古柇林. 误差线是标准差 $(n=3) . \mathrm{a}, \mathrm{b}$ 示同一生态 系统组分在不同森林类型之间 LSD 检验显著性差异分组 $(\alpha=0.05)$

$(57.0 \pm 7.9) \%$. 硬阔叶林的碎屑碳库和植被碳库分配 比例最低(分别为 $1.9 \%$ 和 $35.3 \%$ ), 蒙古栋林的最高 (分别为 $4.3 \%$ 和 $46.8 \%$ ); 而蒙古柇林的土壤碳库分配 比例最低(50.0\%), 硬阔叶林的最高(62.9\%).

植被碳库中，被压木(即树高小于林分平均树高 的林木个体)的 BA 对林分总 BA 的贡献率在 5.7\% 21.8\%之间波动; 而被压木碳密度对乔木层碳 密度 $(\mathrm{OC}$ )的贡献率则在 3.6\% 18.8\% 之间波动(图 3). 其中, 两种人工林中被压木 $\mathrm{BA}$ 和碳密度对林分 $\mathrm{BA}$ 和 $\mathrm{OC}$ 的贡献率显著大于 4 种天然林(BA 贡献率: $F_{5,12}=3.2, P<0.05$; $\mathrm{OC}$ 贡献率: $\left.F_{5,12}=3.4, P<0.05\right)$. 总 
体上, 6 种森林类型被压木 BA 的贡献率均大于 $\mathrm{OC}$ 贡 献率, 但 $t$ 配对差异性检验显示, 红松人工林 $\left(t_{2}=6.6\right.$, $P=0.02)$ 、兴安落叶松林 $\left(t_{2}=12.6, P<0.01\right)$ 和蒙古栋林 $\left(t_{2}=17.0, P<0.01\right)$ 的两个贡献率之间差异显著(图 3).

碎屑碳库中，不同森林类型之间枯立木 $\left(F_{5,12}=\right.$ $2.6, P=0.08)$ 、枯落物 $\left(F_{5,12}=8.8, P<0.01\right)$ 和粗木质残体 $\left(F_{5,12}=4.7, P=0.01\right.$ )的分配比例差异显著(图 4). 两种 人工林的粗木质残体的分配比例(红松林和兴安落叶 松林分别是 3.6\%和 1.0\%)显著低于 4 种天然次生林. 兴安落叶松林的枯落物碳库占总碎屑碳库比例高达 $96.8 \%$.

叶生物量、叶生产效率 $(\mathrm{PF}$, 即总生物量与叶生 物量之比)、中细根生物量和中细根生产效率(PR, 即 总生物量与中细根生物量之比)在 6 种森林类型之间 差异显著(图 5). 叶生物量和中细根生物量分别在 $2.08 \sim 4.72\left(F_{5,12}=8.4, \quad P<0.01\right)$ 和 $0.95 \sim 3.24 \quad \mathrm{tC} / \mathrm{hm}^{2}$ $\left(F_{5,12}=24.6, P<0.01\right)$ 之间波动. $\mathrm{PF}$ 和 $\mathrm{PR}$ 分别在 22.6 $46.0\left(F_{5,12}=8.2, P<0.01\right)$ 和 $36.5 \sim 124.7 \mathrm{~g} / \mathrm{g}\left(F_{5,12}=43.1\right.$, $P<0.01)$ 之间波动. 常绿红松林的 $\mathrm{PF}(22.6 \mathrm{~g} / \mathrm{g})$ 显著低 于其他落叶林 $(\bar{x} \pm \mathrm{SD},(42.4 \pm 3.7) \mathrm{g} / \mathrm{g})$. 兴安落叶松 林的 PR 最高 $(124.7 \mathrm{~g} / \mathrm{g})$, 是落叶阔叶林平均值 $((46.9 \pm$ $13.1) \mathrm{g} / \mathrm{g}$ )的 $266 \%$.

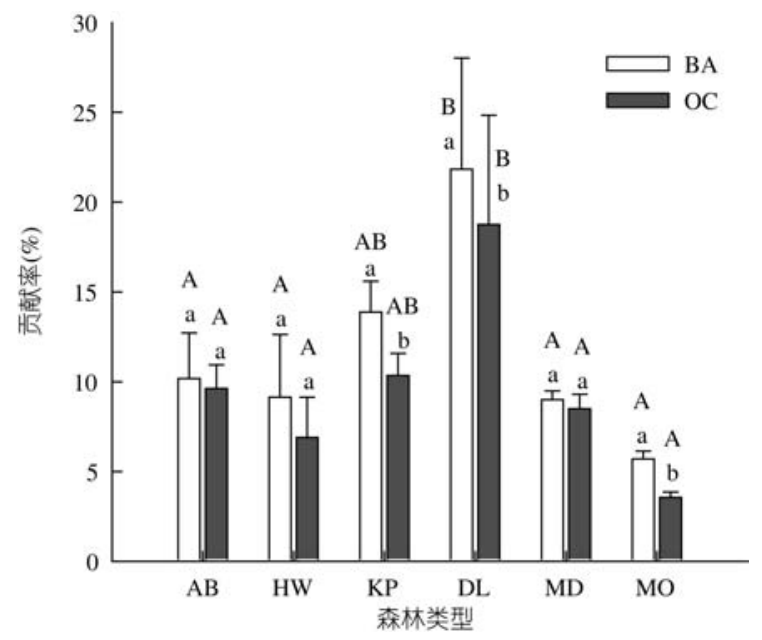

图 3 被压木胸高断面积(BA)和碳密度对林分 BA 和乔木 层碳密度 $(\mathrm{OC})$ 的贡献率

$\mathrm{AB}, \mathrm{HW}, \mathrm{KP}, \mathrm{DL}, \mathrm{MD}$ 和 MO 分别示杨桦林、硬阔叶林、红松林、 兴安落叶松林、杂木林和蒙古栎林. 误差线是标准差 $(n=3) . \mathrm{A}, \mathrm{B}$ 示同一贡献率在不同森林类型之间 LSD 检验显著性差异分组 $(\alpha=0.05) ; \mathrm{a}, \mathrm{b}$ 示同一森林类型内两种贡献率 $t$ 配对检验显著性 差异分组 $(\alpha=0.05)$

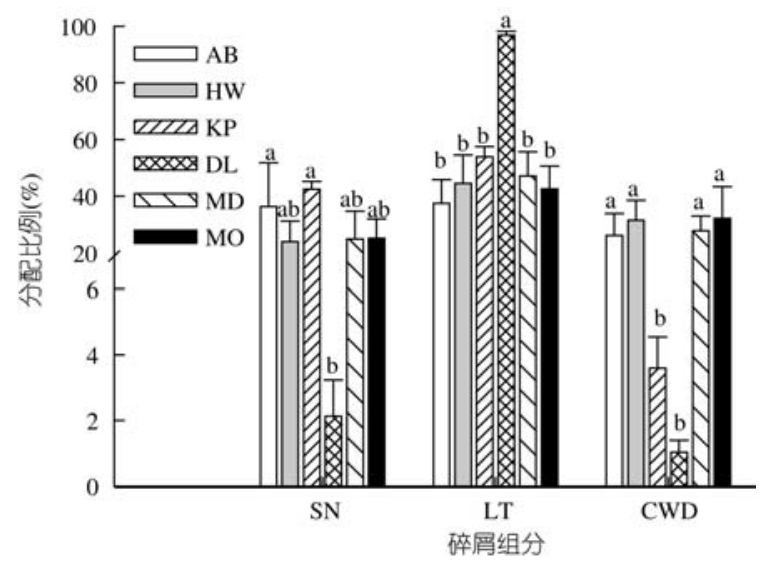

图 46 种森林类型碎屑碳库的分配比例

$\mathrm{SN}, \mathrm{LT}$ 和 CWD 分别示枯立木、枯落物和粗木质残体; AB, HW, KP, DL, MD 和 MO 分别示杨华林、硬阔叶林、红松林、兴安落叶松林、 杂木林和蒙古栋林. 误差线是标准误 $(n=3) . \mathrm{a}, \mathrm{b}$ 示同一碎屑组分 不同森林类型间 LSD 检验显著性差异分组 $(\alpha=0.05)$
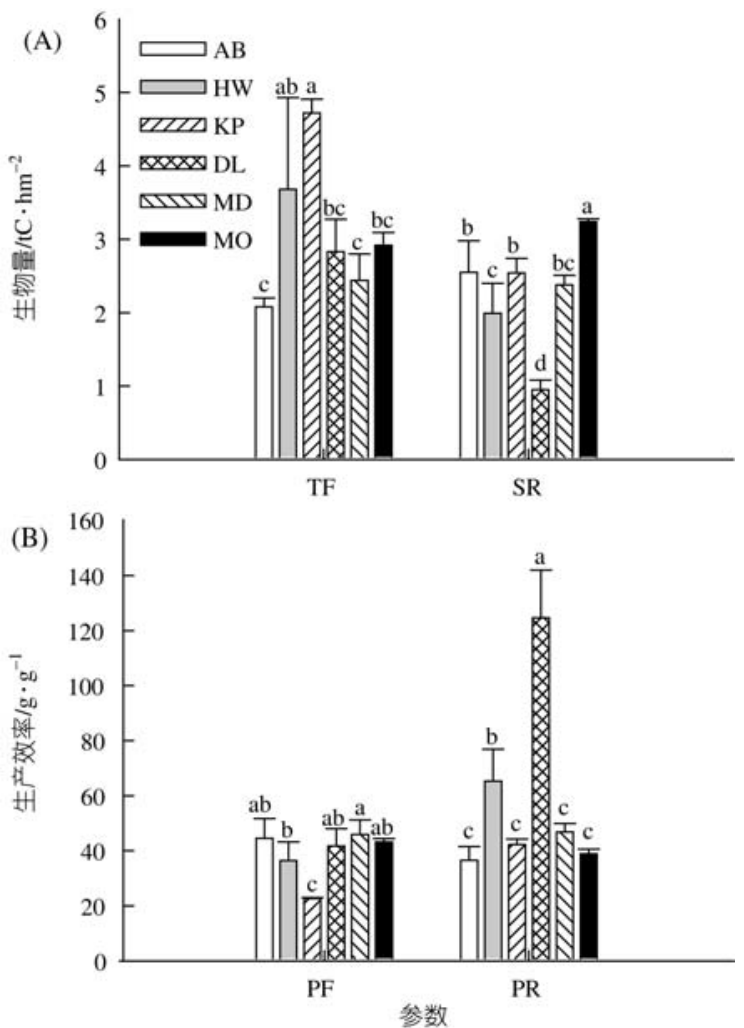

图 56 种森林类型叶和中细根生物量及其生产效率 $\mathrm{TF}, \mathrm{SR}, \mathrm{PF}$ 和 PR 分别示叶生物量、中细根生物量、叶生产效率和 中细根生产效率; $\mathrm{AB}, \mathrm{HW}, \mathrm{KP}, \mathrm{DL}, \mathrm{MD}$ 和 $\mathrm{MO}$ 分别示杨桦林、硬 阔叶林、红松林、兴安落叶松林、杂木林和蒙古柇林. 误差线是 标准差 $(n=3) . \quad \mathrm{a} \sim \mathrm{d}$ 示同一参数在不同森林类型之间 LSD 检验 显著性差异分组 $(\alpha=0.05)$ 
6 种森林类型之间总地下生物量 (TBC: $F_{5,12}=4.0$, $P=0.02) 、$ 根冠比 $\left(R / S: F_{5,12}=3.1, P<0.05\right) 、 中$ 细根生物 量与叶生物量之比(SR/TF: $\left.F_{5,12}=31.2, P<0.01\right)$ 均存在 显著差异 (图 6). TBC 在 18.3 (杨桦林)和 26.9 $\mathrm{tC} / \mathrm{hm}^{2}$ (硬阔叶林)之间波动; $R / S$ 在 $22.0 \%$ (兴安落叶松 林)和 28.3\%(硬阔叶林)之间波动; SR/TF 在 34.5\%(兴 安落叶松林)和 $122.2 \%$ (杨桦林)之间波动.

不同森林类型之间 $\left(F_{5,12}=27.2, P<0.01\right)$ 和土壤层 次之间 $\left(F_{3,68}=33.7, P<0.01\right)$ 的中细根碳密度(包括死活 中细根量)差异显著(图 7). 杨华林、硬阔叶林、红松 林、兴安落叶松林、杂木林和蒙古栋林的中细根碳密 度分别为 $3.72,3.63,3.58,1.67,3.30$ 和 $4.17 \mathrm{tC} / \mathrm{hm}^{2}$. 除蒙古柇林之外, 其他 5 种森林类型的中细根碳密度 均随土壤层次的加深而降低. 其中, $0 \sim 10 \mathrm{~cm}$ 层的中 细根碳密度的分配比例最大,在 $37.5 \%$ 46.7\% 之间波 动. 但蒙古栋林 $10 \sim 20 \mathrm{~cm}$ 层的中细根碳密度最高 $\left(1.28 \mathrm{tC} / \mathrm{hm}^{2}\right)$, 占总中细根碳密度的 $30.6 \%$.

\section{3 讨论}

\section{1 生态系统总碳库}

本研究中的温带次生林和人工林是在顶级群落 阔叶红松原始林屡遭采伐但土壤仍保存较完整下形 成的 ${ }^{[26]}$, 其总碳密度 $\left(186.9 \sim 349.2 \mathrm{tC} / \mathrm{hm}^{2}\right.$, 表 2)的波 动范围大于长白山温带原始林(192.2 256.4 tC/

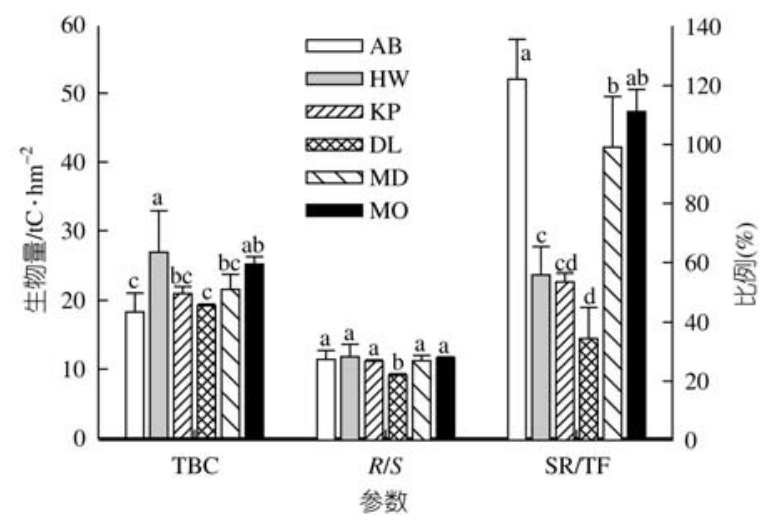

图 66 种森林类型总地下生物量 $(\mathrm{TBC})$ 、根冠比 $(R / S)$ 和中 细根生物量与叶生物量之比 $(S R / T F)$

$\mathrm{AB}, \mathrm{HW}, \mathrm{KP}, \mathrm{DL}, \mathrm{MD}$ 和 MO 分别示杨桦林、硬阔叶林、红松林、 兴安落叶松林、杂木林和蒙古柇林. 误差线是标准差 $(n=3) . \mathrm{a} \sim \mathrm{d}$ 示 同一生态系统组分在不同森林类型之间 LSD 检验显著性 差异分组 $(\alpha=0.05)$

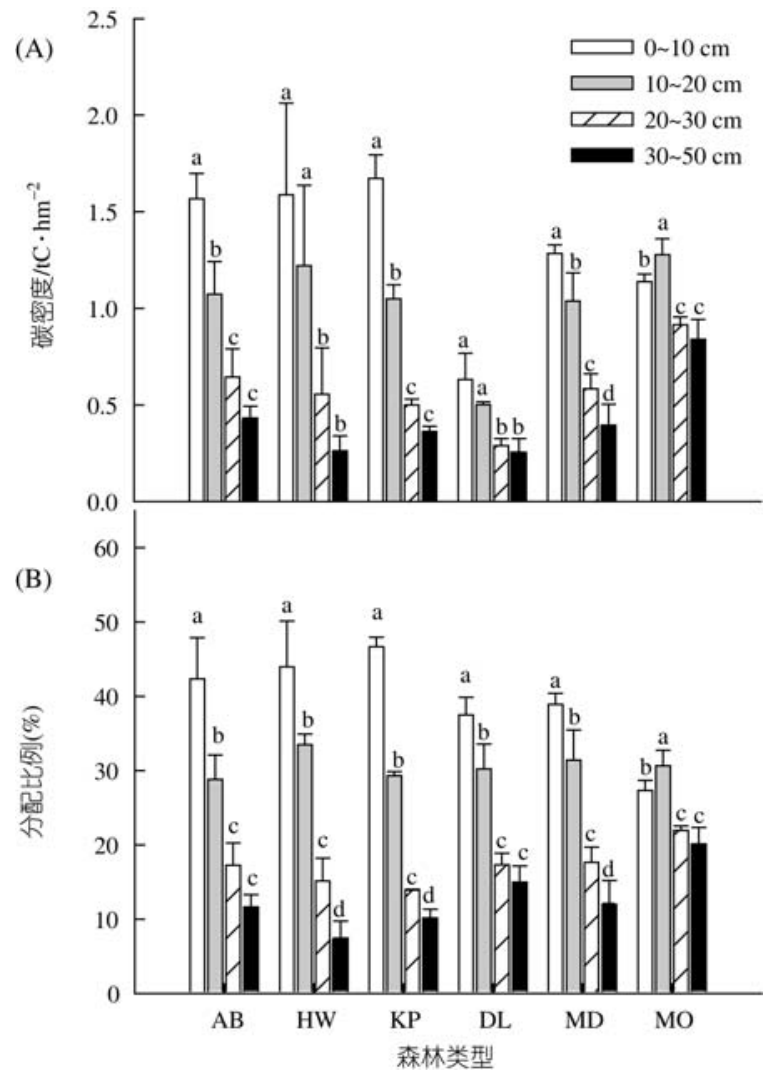

图 76 种森林类型中细根碳密度及其分配比例的垂直 分布

$\mathrm{AB}, \mathrm{HW}, \mathrm{KP}, \mathrm{DL}, \mathrm{MD}$ 和 MO 分别示杨桦林、硬阔叶林、红松林、 兴安落叶松林、杂木林和蒙古柇林. 误差线是标准差 $(n=3) . \mathrm{a} \sim \mathrm{d}$ 示 同一森林类型在不同土壤深度之间 LSD 检验显著性差异分组 $(\alpha=0.05)$

$\left.\mathrm{hm}^{2}\right)^{[20]}$, 高于温带森林(林龄在 31 70 年)的平均值 ((189 \pm 58$\left.) \mathrm{tC} / \mathrm{hm}^{2}\right)^{[18]}$. 表明本地区温带森林具有较高 的碳密度, 同时也意味着干扰可能会增加森林碳密 度的空间分异.

6 种森林类型所处的气候条件完全一致，林龄相 近(42 59 年), 但所处的立地条件、经营措施和植被 组成差异较大 (表 1). 尽管如此, 不同森林类型之间 的生态系统组分碳密度(碎屑碳库除外)均无显著差 异(表 2). 这意味着在相同气候条件下不同森林林型 的碳密度有趋同趋势. 同时, 该结果与以往一些研究 结果似乎不符 ${ }^{[14,32]}$. 然而, 进一步将碳密度用乔木层 的胸高断面积(BA)标准化后发现, 森林类型之间碳 密度的差异显著(图 1). 这说明植被组成、立地条件、 经营措施等的不同可能影响 BA, 进而导致森林碳密 度和碳分配格局产生分异. 
生态系统碳分配格局随森林类型和生态系统组 分而变(图 2). 然而, 不论是哪种森林, 其总碳库的绝 大部分被分配到植被碳库和土壤碳库中, 分配系数 高达 90\%以上.

\section{2 植被碳库及其分配}

6 种森林类型的植被碳密度处在东北温带森林的 变化范围内 $\left(5.5 \sim 216 \mathrm{tC} / \mathrm{hm}^{2}\right)$, 但高于 Wang 等人 ${ }^{[33]}$ 估 测的温带天然次生林 $\left(61 \mathrm{tC} / \mathrm{hm}^{2}\right)$ 和人工林的平均值 $\left(44 \mathrm{tC} / \mathrm{hm}^{2}\right)$, 更接近温带原始林的平均值 (106 $\mathrm{tC} / \mathrm{hm}^{2}$ ). 表明本研究中的森林碳积累已经接近森林 发展过程中较稳定阶段.

在生态系统总碳库中, 植被碳库的分配系数变 化在 1/3 1/2 之间(表 2 和图 2), 低于长白山不同海拔

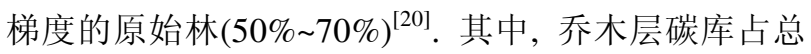
植被碳库的 $99 \%$ 以上(表 2), 而林下植被层所占比例 非常小(在 $0.04 \%$ 1\%之间波动), 与长白山原始林接 近 $(0.5 \% \text { 2.5\%) })^{[20]}$. 地下生物量(图 6)与 Wang 等人 ${ }^{[33]}$ 报道的东北天然林接近, 介于北方森林 ${ }^{[19,34]}$ 和热带 雨林 ${ }^{[35]}$ 之间. 其中, 中细根生物量(图 5(A)) 与 Jackson 等人 ${ }^{[36]}$ 综述的温带森林的平均值接近.

胸高断面积(BA)是森林生态系统(尤其是天然林) 中树木对养分、水分、光照等竞争作用结果的体现, 是估算植被组成相同或相近的森林生物量的一个简 便因子 ${ }^{[37]}$. 将本研究中的 4 种天然林乔木层碳密度与 其 BA 进行回归分析发现，两者之间存在显著的正相 关关系, 而两种人工林乔木层碳密度与其 $\mathrm{BA}$ 之间有 负相关趋势(图 8). 这种天然林和人工林的乔木层碳 密度与 BA 的关系不一可能与林分中小径级林木 (即 被压木) BA 和碳密度的贡献率差异有关. 本研究中, 兴安落叶松人工林被压木 $\mathrm{BA}$ 对林分 $\mathrm{BA}$ 的贡献率高 达 $21.8 \%$, 而被压木碳密度对乔木层碳密度的贡献率 为 $18.8 \%$, 前者显著高于后者(图 3). 说明在 $\mathrm{BA}$ 相同 的林分中, 被压木占的比例越大, 则林分的生物量碳 密度越低. 再者, 相同 BA 的硬阔叶林乔木层碳密度 高出其他 3 种天然林的近 24\%, 主要是由于组成树种 的碳浓度 ${ }^{[30]}$ 和木材密度 ${ }^{[38}$ 差异所致. 硬阔叶林主要 组成树种的碳浓度(水曲柳和胡桃梑的质量加权平均 碳浓度分别为 $52.9 \%$ 和 $52.4 \%$ )均高于其他 3 种森林类 型的主要组成树种(蒙古栎、山杨、白桦的质量加权 平均碳浓度分别为 $47.6 \%, 43.7 \%$ 和 $46.1 \%)^{[30]}$, 这部 分差异将导致碳密度相对误差近 $7 \%$. 此外, 组

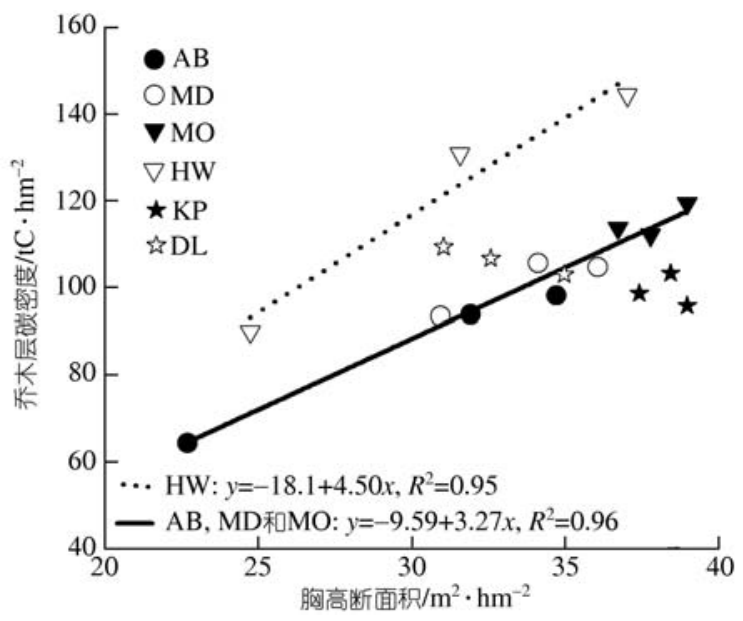

图 84 个天然林乔木层碳密度 $(y)$ 与胸高断面积 $(x)$ 之间的 关系

$\mathrm{AB}, \mathrm{HW}, \mathrm{KP}, \mathrm{DL}, \mathrm{MD}$ 和 MO 分别示杨桦林、硬阔叶林、红松林、 兴安落叶松林、杂木林和蒙古柇林. 回归方程的 $P$ 值均小于 0.01

成林分的木材密度 ${ }^{[38]}$ 和树高(表 1)的差异也会导致森 林类型之间碳密度的差异. 综上所述，林分胸高断面 积、组成树种的碳浓度、林木径级分布、木材密度等 都会影响植被的碳密度.

叶是植物进行光合固碳和蒸腾耗水的主要功能 器官, 而细根则是植物吸收养分和水分的主要功能 器官. 植被碳库中叶和细根的分配反映了森林的固 碳能力和碳源汇强度. 树木根据其自身的生理生态 特性和所处立地的养分状况 ${ }^{[39,40]}$ 、水分有效性 ${ }^{[13,41 \sim 43]}$ 等合理地配置功能器官的比例. 本研究中, 红松林的 叶生产效率(22.6\%)仅为其他落叶林的 1/2(图 5). 这意 味着具有相同生物量的林分, 常绿林所拥有的叶量显 著地高于落叶林. 这与以往的研究结果相符 ${ }^{[17,44]}$. 然 而, 兴安落叶松林和硬阔叶林的中细根生产效率显 著高于其他森林类型(图 5). 森林类型之间的这种地 下碳分配格局差异除了与植被组成有关之外，还与 土壤的水分和养分状况有关. 兴安落叶松林和硬阔 叶林生长在土壤含水率较高、土壤较肥沃的平坦沟谷 地带(表 1), 因而其树木为获取其生长和维持代谢活 动所需要的养分和水分的投资较少; 相反, 生长在山 坡中上部较干旱贫㾑立地上的杨华林、杂木林和蒙古 栎林, 为保证树木的生存和生长, 就需要增加对细根 分配的投资. 此外, 从不同森林类型中细根碳密度的 垂直分布格局(图 7)也可看出，林分的树种组成及其所 处的立地条件(表 1)影响中细根的生长和碳分配. 有研 
究表明, 分布在不同深度的根, 其功能有别 ${ }^{[45]}$. 浅层 根侧重于获取养分, 而深层根则侧重于摄取水分 ${ }^{[46]}$. 由于森林土壤的养分集中在表层 ${ }^{[47]}$, 因此所有森林 类型(蒙古楿林除外)的中细根碳库均集中在土壤表 层, 其 $0 \sim 30 \mathrm{~cm}$ 土层的中细根碳库占总中细根碳库的 $85 \%$ 以上(图 7). 然而, 蒙古柇林中细根的垂直分布 则趋于下移, 其中细根碳库中约有 $20 \%$ 分布在 $30 \mathrm{~cm}$ 以下. 这与蒙古楿树木特性和所处的干旱瘦薄的立 地条件有关 (表 1). 该结果与以往在相同森林类型相 同样地上用微根管方法测得的结果一致 ${ }^{[29]}$. 综上所 述, 叶碳分配主要受控于树种特性, 而中细根碳分配 则主要受控于土壤水分和养分状况.

根冠比 $(R / S)$ 与叶生物量(或叶面积)和中细根生物 量分配有所不同, 它能综合反映植物吸收和生产的平 衡 ${ }^{[8]}$. 因此, $R / S$ 常作为表征植物代谢功能和碳分配的 一个重要指标. 它受降水量、土壤水分有效性、地上 生物量、林龄及森林起源等的综合影响 ${ }^{[33]}$. 本研究的 $R / S$ 变化范围(22\% 28\%)(图 6), 处于以往研究结果中 森林 $R / S^{[49]}$ 的变化范围之内, 与东北森林 $R / S$ 的平均值 $(27 \%)$ 接近 ${ }^{[33]}$. 其中, 兴安落叶松林是一种特殊的落叶 针叶林 ${ }^{[50]}$, 其 $R / S$ 明显低于其他 5 种森林类型.

\section{3 碎屑碳库及其分配}

本研究中, 平均碎屑碳库分配比例约为 $3.3 \%$ (表 $2)$, 处于长白山温带原始林的变化范围内 $(2 \% \text { 9\% })^{[20]}$, 但高于东灵山 3 种温带森林 $(2.8 \%)^{[51]}$, 却远低于不同 林龄的北方杂木林 $(23 \% \text { \% } 7 \%)^{[34]}$. 碎屑碳密度受森林 类型、立地条件、经营状况等的影响较大. 从较湿润 硬阔叶林到较干燥蒙古柇林, 碎屑碳密度有增加的趋 势(表 2 和图 2). 这与以往温带森林的研究 ${ }^{[17,52]}$ 相符, 但总体上均低于林龄相近的北方黑云杉林 ${ }^{[19]}$. 产生 该差异的原因除了植被状况引起碎屑碳输入的差异 之外, 还与环境因子控制的碎屑分解速度和林分的 经营历史有关. 粗木质残体碳库主要受林龄、林分结 构和干扰的影响 ${ }^{[53]}$. 本研究中的两种人工林的粗木 质残体碳密度很低, 远低于其他 4 种天然林 (表 2). 这 可能主要由经营历史的差异所致.

在碎屑碳库中, 地表枯落物层是森林碳循环中 最活跃的组分 ${ }^{[5]}$. 本研究中, 兴安落叶松林的地表枯 落物碳密度最大 $\left(9.6 \mathrm{tC} / \mathrm{hm}^{2}\right)$, 显著高于其他 5 种森林 类型, 而与大兴安岭草地兴安落叶松林相近 ${ }^{[14]}$. 这可 能与兴安落叶松林所处的阴湿环境(表 1)和较难分解
的针叶 ${ }^{[55,56]}$ 有关. 枯落物碳库受物理环境、调落物的 数据和质量及微生物群落特性的影响 ${ }^{[57]}$. 兴安落叶 松林每年枯落物的输入量 $\left(145.0 \mathrm{gC} \cdot \mathrm{m}^{-2} \cdot \mathrm{a}^{-1}\right)$ 最低(杨 华林、硬阔叶林、红松林、杂木林和蒙古栎林的调落 量分别为 $178.4,176.7,153.5,183.1$ 和 $171.8 \mathrm{gC} \cdot \mathrm{m}^{-2} \cdot \mathrm{a}^{-1}$ (未发表资料)。没有测定土壤微生物群落特性, 但 以往研究显示, 兴安落叶松林的土壤呼吸显著低于 其他森林类型 ${ }^{[28]}$, 而且林地枯落物量与土壤呼吸年 通量呈显著负相关关系 $(r=-0.79)$. 这说明分解缓慢 可能是导致兴安落叶松林林地枯落物积累的主要原 因.

\section{4 土壤碳库及其分配}

本研究中的土壤碳密度 (93.7 220.1 tC/ $\mathrm{hm}^{2}$, 表 2)与以往温带森林土壤碳库研究结果 ${ }^{[58]}$ 接近, 但高 于长白山温带原始林(62.7 88.7 tC/ $\left.\mathrm{hm}^{2}\right)^{[20]}$. 这说明 本研究的森林土壤固碳潜力显著地高于地处纬度较 低、海拔较高的长白山温带森林.

土壤是母质、地形、时间、气候、生物因素等共 同作用的结果，其中前两个因素比较稳定，而后两个 因素相对活跃. 在特定的森林生态系统中, 其土壤碳 库的分异主要受控于气候和植被功能型的长期共同 作用 ${ }^{[58,59]}$. 本研究中各个森林类型的土壤碳库分配 比例在 50\% 63\%之间波动(表 2 和图 2), 远低于北京 东灵山 3 种温带森林 $(80 \%)^{[51]}$ 和北方老龄黑云杉林 $(88 \%)^{[19,32]}$ 的平均值, 高于北方森林 $(20 \% \sim 44 \%)^{[32,34]}$ 、

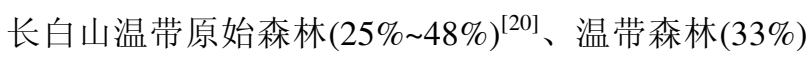
和热带森林 $(36 \%)$ 的平均值 ${ }^{[12]}$. 因此, 不同地理、气候 和植被类型下的土壤碳库分配比例差异较大.

\section{4 结论}

林龄相近但处于不同立地条件和植被组成的 6 种温带森林, 其生态系统组分碳密度(碎屑碳库除外) 差异不显著, 但用林分胸高断面积标准化之后则存 在显著差异. 这表明胸高断面积是森林类型之间碳 密度比较时需要考虑的重要因子之一. 然而, 森林类 型之间的碳分配格局差异显著. 在相同气候条件下 的特定森林中, 其碳分配格局的分异主要受植被类 型、经营历史、局域土壤的水分和养分有效性等因素 的共同作用. 在植被碳库中, 叶碳分配主要受控于树 种特性, 而中细根碳分配则主要受控于土壤水分和 
养分状况. 该研究为温带森林碳循环模型提供了重要的构建和校验参数.

致谢＼cjkstart感谢东北林业大学林学院全先奎、王兴昌、刘爽、许飞、唐艳、许智伟等在野外和室内实验中提供的帮助、 帽儿山森林生态站提供的野外基础支持.

参考文献

1 FAO. Global Forest Resource Assessment: Progress Towards Sustainable Forest Management. In: FAO, ed. Rome: FAO Forestry Paper, 2005. 147

2 方精云, 朴世龙, 赵淑清. $\mathrm{CO}_{2}$ 失汇与北半球中高纬度陆地生态系统的碳汇. 植物生态学报, 2001, 25: 594一602

3 Goodale C L, Apps M J, Birdsey R A, et al. Forest carbon sinks in the northern hemisphere. Ecol Appl. 2002, 12: 891—899

4 Myneni R B, Dong J, Tucker C J, et al. A large carbon sink in the woody biomass of northern forests. Proc Natl Acad Sci USA, 2001, 98: $14784-14789$

5 White A, Cannell M G R, Friend A D. The high-latitude terrestrial carbon sink: a model analysis. Glob Change Biol, 2000, 6: 227-245

6 Melillo J M, McGuire A D, Kicklighter D W, et al. Global climate change and terrestrial net primary production. Nature, 1993, 363: 234240

7 Cao M, Woodward F I. Dynamic responses of terrestrial ecosystem carbon cycling to global climate change. Nature, 1998, 393: 249-252

8 Jastrow J D, Miller R M, Matamala R, et al. Elevated atmospheric carbon dioxide increases soil carbon. Glob Change Biol, 2005, 11: 20572064

9 Phillips O L, Malhi Y, Higuchi N, et al. Changes in the carbon balance of tropical forests: evidence from long-term plots. Science, 1998, 282: $439-442$

10 Schimel D S, House J I, Hibbard K A. Recent patterns and mechanisms of carbon exchange by terrestrial ecosystems. Nature, 2001, 414: $169-172$

11 Dixon R K, Brown S, Houghton R A, et al. Carbon pools and flux of global forest ecosystems. Science, 1994, 263: 185 - 190

12 Malhi Y, Baldocchi D D, Jarvis P G. The carbon balance of tropical, temperate and boreal forests. Plant Cell Environ, 1999, 22: 715-740

13 Litton C M, Raich J W, Ryan M G. Carbon allocation in forest ecosystems. Glob Change Biol, 2007, 13: 2089-2109

14 Wang C, Gower S T, Wang Y, et al. The influence of fire on carbon distribution and net primary production of boreal Larix gmelinii forests in north-eastern china. Glob Change Biol, 2001, 7: 719-730

15 Law B E, Thornton P E, Irvine J, et al. Carbon storage and fluxes in ponderosa pine forests at different developmental stages. Glob Change Biol, 2001, 7: 755-777

16 Litton C, Ryan M, Knight D. Effects of tree density and stand age on carbon allocation patterns in postfire lodgepole pine. Ecol Appli, 2004, 14: $460-475$

17 Peichl M, Arain A A. Above- and belowground ecosystem biomass and carbon pools in an age-sequence of temperate pine plantation forests. Agr For Meteor, 2006, 140: 51-63

18 Pregitzer K S, Euskirchen E S. Carbon cycling and storage in world forests: biome patterns related to forest age. Glob Change Biol, 2004, 10: $2052-2077$

19 Wang C, Bond-lamberty B, Gower S T. Carbon distribution of a well- and poorly-drained black spruce fire chronosequence. Glob Change Biol, 2003, 9: 1066-1079

20 Zhu B, Wang X, Fang J, et al. Altitudinal changes in carbon storage of temperate forests on Mt Changbai, northeast china. J Plant Res, 2010, 123: $439-452$

21 Litton C M, Ryan M G, Tinker D B, et al. Belowground and aboveground biomass in young postfire lodgepole pine forests of contrasting tree density. Can J For Res, 2003, 33: 351-363

22 Fang J, Guo Z, Piao S, et al. Terrestrial vegetation carbon sinks in china, 1981 2000. Sci China: Earth Sci, 2007, 50: 1341-1350

23 Luyssaert S, Inglima I, Jung M, et al. $\mathrm{CO}_{2}$ balance of boreal, temperate, and tropical forests derived from a global database. Glob Change Biol, 2007, 13: 2509-2537

24 杨金艳, 王传宽. 东北东部森林生态系统土壤碳咜量和碳通量. 生态学报, 2005, 25: 2875-2882

25 Peng C, Zhou X, Zhao S, et al. Quantifying the response of forest carbon balance to future climate change in northeastern China: Model 
validation and prediction. Glob Planet Change, 2009, 66: 179-194

Wang C. Biomass allometric equations for 10 co-occurring tree species in Chinese temperate forests. For Ecol Manag, 2006, 222: 9-16

Piao S, Fang J, Ciais P, et al. The carbon balance of terrestrial ecosystems in China. Nature, 2009, 458: 1009-1013

Wang C K, Yang J Y, Zhang Q Z. Soil respiration in six temperate forests in China. Glob Change Biol, 2006, 12: 2103-2114

Zhang Q, Wang C, Wang X, et al. Carbon concentration variability of 10 Chinese temperate tree species. For Ecol Manag, 2009, 258: 722727

31 Vogt K A, Vogt D J, Bloomfield J. Analysis of some direct and indirect methods for estimating root biomass and production of forests at an ecosystem level. Plant Soil, 1998, 200: 71-89

32 Gower S T, Vogel J G, Norman J M, et al. Carbon distribution and aboveground net primary production in aspen, jack pine, and black spruce stands in Saskatchewan and Manitoba, Canada. J Geophys Res, 1997, 102: 29029-29042

33 Wang X P, Fang J Y, Zhu B. Forest biomass and root-shoot allocation in northeast China. For Ecol Manag, 2008, 255: 4007-4020

34 Martin J L, Gower S T, Plaut J, et al. Carbon pools in a boreal mixedwood logging chronosequence. Glob Change Biol, 2005, 11: 1883-1894

35 Vargas R, Allen M F, Allen E B. Biomass and carbon accumulation in a fire chronosequence of a seasonally dry tropical forest. Glob Change Biol, 2008, 14: 109-124

36 Jackson R, Mooney H, Schulze E. A global budget for fine root biomass, surface area, and nutrient contents. Proc Natl Acad Sci USA, 1997, 94: 7362

37 Chiba Y. Architectural analysis of relationship between biomass and basal area based on pipe model theory. Ecol Model, 1998, 108: 219225

38 Baker T, Phillips O, Malhi Y, et al. Variation in wood density determines spatial patterns in Amazonian forest biomass. Glob Change Biol, 2004, 10: 545-562

39 Helmisaari H, Derome J, Nojd P, et al. Fine root biomass in relation to site and stand characteristics in Norway spruce and Scots pine stands. Tree Physiol, 2007, 27: 1493

40 Makela A, Valentine H T, Helmisaari H S. Optimal co-allocation of carbon and nitrogen in a forest stand at steady state. New Phytol, 2008, 180: $114-123$

41 Litton C M, Giardina C P. Below-ground carbon flux and partitioning: Global patterns and response to temperature. Funct Ecol, 2008, 22: $941-954$

42 Aber J, Melillo J, Nadelhoffer K, et al. Fine root turnover in forest ecosystems in relation to quantity and form of nitrogen availability: a comparison of two methods. Oecologia, 1985, 66: 317-321

43 Pastor J, Post W. Influence of climate, soil moisture, and succession on forest carbon and nitrogen cycles. Biogeochemistry, 1986, 2: 3-27

44 Vande Walle I, Mussche S, Samson R, et al. The above- and belowground carbon pools of two mixed deciduous forest stands located in east-Flanders (Belgium). Ann For Sci, 2001, 58: 507-517

45 Canadell J, Jackson R, Ehleringer J, et al. Maximum rooting depth of vegetation types at the global scale. Oecologia, 1996, 108: 583-595

46 Brassard B W, Chen H Y H, Bergeron Y. Influence of environmental variability on root dynamics in northern forests. Crit Rev Plant Sci, 2009, 28: 179-197

47 Jobbágy E, Jackson R. The distribution of soil nutrients with depth: global patterns and the imprint of plants. Biogeochemistry, 2001, 53: 5177

48 Kozlowski T T, Pallardy S G. Physiology of Woody Plants. San Diego: Academic Press, 1996

49 Jackson R B, Canadell J, Ehleringer J R, et al. A global analysis of root distributions for terrestrial biomes. Oecologia, 1996, 108: 389-411

50 Gower S T, Richards J H. Larches: deciduous conifers in an evergreen world. Bioscience, 1990, 40: 818 - 826

51 Fang J Y, Liu G H, Zhu B, et al. Carbon budgets of three temperate forest ecosystems in Dongling Mt., Beijing, China. Sci China Ser D: Earth Sci, 2007, 50: 92-101

52 Gough C, Vogel C, Kazanski C, et al. Coarse woody debris and the carbon balance of a north temperate forest. For Ecol Manag, 2007, 244: $60-67$

53 Sturtevant B, Bissonette J, Long J, et al. Coarse woody debris as a function of age, stand structure, and disturbance in boreal Newfoundland. Ecol Appl, 1997, 7: 702-712

54 Yanai R, Arthur M, Siccama T, et al. Challenges of measuring forest floor organic matter dynamics: repeated measures from a chronosequence. For Ecol Manag, 2000, 138: 273-283

55 Cornelissen J, Grime J, Marzano B, et al. Leaf structure and defence control litter decomposition rate across species and life forms in 
regional floras on two continents. New Phytol, 1999, 143: 191-200

56 Liu S, Li X, Niu L. The degradation of soil fertility in pure larch plantations in the northeastern part of China. Ecol Engineering, 1998, 10: $75-86$

57 Chapin III F S, Matson P A, Mooney H A. Principles of Terrestrial Ecosystem Ecology. New York: Springer-Verlag, 2002

58 Jobbágy E, Jackson R. The vertical distribution of soil organic carbon and its relation to climate and vegetation. Ecol Appl, 2000, 10: 423436

59 Binkley D. The influence of tree species on forest soils: processes and patterns. Agron Soc New Zealand Special Publication, 1995, 10: 134 